\title{
Inhibiting Tomato Ripening with 1-Methylcyclopropene
}

\author{
Nazir Mir, ${ }^{1}$ Mauricio Canoles, ${ }^{2}$ and Randolph Beaudry ${ }^{3}$ \\ Postharvest Technology and Physiology Laboratory, Department of Horticulture, Michigan State \\ University, East Lansing, MI 48824 \\ Elizabeth Baldwin \\ U.S. Department of Agriculture, Agricultural Research Service, Citrus and Subtropical Products \\ Laboraory, Winter Haven, FL 33883 \\ Chhatar Pal Mehla \\ Haryana Agricultural University, Hisar, India
}

AdDitional INDEX WORDs. Lycopersicon esculentum, 1-MCP, firmness, color, quality, locule, aroma

\begin{abstract}
Aвstract. The capacity for 1-methylcyclopropene (1-MCP) to inhibit color change and firmness loss and alter aroma profiles for tomato (Lycopersicon esculentum Mill.) fruit was evaluated as a function of 1-MCP concentration, multiple and continuous applications, and stage of ripeness. In addition, the relationship between external and internal fruit color and firmness was determined. 1-MCP reduced the rate of red color development in fruit of all stages of ripeness. A single application of 1-MCP delayed color development by $\approx 6$ days. A second application of 1-MCP 10 days after first treatment additionally delayed color development of mature green fruit by another 8 to 10 days. Continuous 1-MCP application completely inhibited color development of breaker and half-ripe fruit for the duration (34 days) of application, but only partially inhibited firmness loss. When fruit at $50 \%$ color development were treated with 1 MCP, gel color development tended to lag behind the external fruit color change compared to nontreated fruit. Some aroma volatiles were affected by 1-MCP applied at the mature green and breaker stages, but the effect was relatively minor; 1-MCP did not affect sugar or titratable acid levels in these fruit. Collectively, the data indicate 1-MCP caused minor shifts in the quality attributes of locule color, aroma, and firmness relative to external color, which may reduce the value of this treatment, but benefits accrued by slowed firmness loss and color development may afford sufficient compensation to make 1-MCP application commercially feasible.
\end{abstract}

Controlling tomato (Lycopersicon esculentum Mill.) fruit ripeness and quality throughout the distribution chain is a priority for the United States commercial fresh tomato industry. Typically, mature green fruit are harvested and the fruit are then ripened for 2 to $3 \mathrm{~d}$ using a controlled ethylene application to initiate and synchronize fruit ripening. Elimination of immature green tomatoes from the market by harvesting fruit after the onset of external red color formation would boost overall tomato flavor quality (Maul et al., 1998a, 1998b).

Mature green tomatoes comprise four stages of ripening based on locular gel development (Kader and Morris, 1976). Stages 1 and 2 have solid locular tissue that can only be determined by cutting the fruit open. These fruit will eventually ripen, albeit with poor quality (Kader et al., 1978; Maul et al., 1997, 1998a, 1998b). Unfortunately, immature green fruit can comprise an average of $31 \%$ to $49 \%$ of fruit intended to be harvested at the mature green stage because of the difficulty in distinguishing them from the mature green fruit based on surface color (Maul et al., 1998b). Mature green tomatoes at stages 3 and 4 contain gelatinous locular tissue, some internal red pigment in green stage 4 , and ripen with good quality.

Ethylene plays a central role in initiating and accelerating ripening-related processes that we perceive as changes in qual-

Received for publication 24 July 2002. Accepted for publication 10 July 2003. We thank Charles Vavrina for providing plant material in the off-season. Research supported by the Project for Generating Research and Extension to meet Economic and Environmental Needs (GREEEN). Use of trade names does not imply endorsement of the products named or criticism of similar ones not named.

${ }^{1}$ Currently vice president of product development, Mid-Atlantic Perishable Commodities Services, 201 Falem Rd. Moorestown, NJ 08057.

${ }^{2} \mathrm{PhD}$ student.

${ }^{3}$ Professor, to whom reprint requests should be addressed; e-mail beaudry@pilot.msu.edu. ity (i.e., color, firmness, soluble solids, acidity, and flavor) in tomato. Treatment of tomatoes with silver ions has been shown to inhibit ethylene action and prevent ripening (Hobson et al., 1984). Further, if silver ions are applied at stages of ripeness well after the breaker stage, ripening can be arrested (Tucker and Brady, 1987). These data were taken to indicate that tomatoes, unlike many other climacteric fruit, require constant ethylene action for ripening to progress. Thus, there is the potential for the use of growth regulators that reduce ethylene perception for the purpose of controlling the ripening process in tomato at various stages of ripening development.

The growth regulator 1-methylcyclopropene (1-MCP), like silver ions, is an extremely effective ethylene antagonist for plants or harvested plant products (Serek et al., 1995a,1995b,1995c; Sisler and Blankenship, 1996; Sisler et al., 1996). Serek et al. (1995a) reported that 1-MCP applied before the initiation of ripening can prevent tomatoes from responding to applied ethylene for a period of several days. As has been demonstrated for silver (Tucker and Brady, 1987), 1-MCP can arrest tomato ripening at various stages of ripeness (Hoeberichts et al., 2002; Mir et al., 1999; Rohwer and Gladon, 2001; Wills and Ku, 2002). Given the ability of 1-MCP to arrest ripening even at advanced stages of fruit ripening, it was anticipated that multiple or continuous exposures of tomatoes to $1-\mathrm{MCP}$ would prolong ripening suppression independent of the initial ripeness of the fruit.

We designed a series of experiments to determine the physiological responsiveness of tomatoes to 1-MCP. Specifically, we measured the effects of 1-MCP concentration on color development; the effects of single, double, and continuous applications on color development and fruit firmness; the ability of 1-MCP to arrest ripening at various ripeness stages; the effects of single applications on locule color, sugar and acid content, and aroma 
volatile formation as they relate to external color; and the effect of 1-MCP on the variability of fruit color after recovery from treatment and subsequent ripening.

\section{Materials and Methods}

APPliCation OF Various CONCENTRATIONS. Fruit of the Romatype tomato 'Plum Dandy' were harvested on 28 Aug. 1998 at the Horticulture Teaching and Research Center (HTRC) at Michigan State University (MSU). Fruit were harvested without calyxes at the turning stage of development (fruit with 10\% to $30 \%$ of the surface having some red coloration), which is equivalent to USDA stage 3 (USDA, 1975, 1976) and transported to the laboratory. Twenty-four fruit were selected for uniformity of surface color and divided into 12 sets of two fruit each. Two fruit were placed into each of twelve 1-L jars and treated with $0,10,20,30,40$, $50,60,70,80,90,100$, and $1000 \mathrm{~nL} \cdot \mathrm{L}^{-1} 1-\mathrm{MCP}$ for $16 \mathrm{~h}$ at room temperature. Fruit color (hue, $\mathrm{H}^{\circ}$ ) was measured on a daily basis using a chromameter (model CR 300; Minolta Camera Co., Osaka, Japan) calibrated using illuminant $\mathrm{C}$ and a white reference plate. Color was measured on three equidistant points along the equator of the fruit, with one site being selected from the most highly colored side of the fruit when possible. The locations for color measurements were indicated on the surface of the fruit using an indelible marker. Data for color change were fitted empirically using line-fitting software (Table Curve, Jandel Scientific, Inc., Chicago, Ill.) to an exponential curve of the form hue ${ }_{\text {skin }}=\mathrm{A}+$ $(\mathrm{B} /(1+\exp (-($ days $-\mathrm{C}) / \mathrm{D})))$, where $\mathrm{A}, \mathrm{B}, \mathrm{C}$, and $\mathrm{D}$ are variables that changed with 1-MCP concentration. The rate of hue change as a function of time was determined by calculating the first derivative of the fitted curve.

A concentrated stock of 1-MCP gas was prepared from EthylBloc (Biotechnologies for Horticulture, Inc., Burr Ridge, Ill.). About $0.05 \mathrm{~g}$ of EthylBloc powder was placed into $25-\mathrm{mL}$ glass vials with a septum in the lid. To release the 1-MCP from the cyclodextrin matrix of EthylBloc, $\approx 100 \mu \mathrm{L}$ of $1 \mathrm{~N} \mathrm{KOH}$ was injected through the vial cap and the vial was shaken for 2 to $3 \mathrm{~s}$. The vials were held for $2 \mathrm{~h}$ to ensure complete release of 1-MCP gas. The 1-MCP concentration in the vial was measured using a gas chromatograph (see below) and the volume of the headspace needed to achieve the target level in the 1-L treatment chambers was withdrawn by syringe and injected into the treatment chambers containing fruit. The treatment chambers were gently spun two or three revolutions to encourage gas mixing. At the conclusion of the treatment, chambers were opened and fruit were removed for color measurements and replaced. Afterward, 1-MCP was no longer detectable in the chamber

Analysis for 1-MCP was performed using a 1-mL gas sample withdrawn from the container or chamber of interest. Gas was analyzed by gas chromatography (Carle AGC series 100; Hach Co., Loveland, Colo.) equipped with a flame ionization detector (FID). The column (Chromosorb 103, 60/80 mesh Supelcoport, Supelco, Bellefonte, Penn.) was maintained at $110^{\circ} \mathrm{C}$. Helium was used as a carrier gas at a flow rate of $35 \mathrm{~mL} \cdot \mathrm{min}^{-1}$. A $1-\mu \mathrm{L}^{\cdot} \mathrm{L}^{-1}$ mixture of 1-butene gas (AGA Gas Co., Maumee, Ohio) in air was used as an external standard.

SINGLE AND DOUBLE APPLICATIONS AT VARIOUS STAGES OF DEVELOPMENT. 'Plum Dandy' tomatoes were harvested without calyxes on 8 Sept. 1998 at the HTRC at MSU and immediately transported to the laboratory. Fruit were sorted to select those free from surface defects and having the greatest uniformity in size and color for study. Fruit were sorted into five maturity classes, mature green (fruit having no external red coloration, hue averaging $112 \mathrm{H}^{\circ}$, USDA stage 1 ), breaker ( $\approx 10 \%$ of fruit surface having some red color development, hue averaging $102 \mathrm{H}^{\circ}$, USDA stage 2), pink $(\approx 50 \%$ of fruit surface having some red color development, hue averaging $75 \mathrm{H}^{\circ}$, USDA stage 4), light red (fruit light red to red in color on $60 \%$ to $90 \%$ of the fruit surface, hue averaging $65 \mathrm{H}^{\circ}$, USDA stage 5), and red (90\% to $100 \%$ of fruit surface a red in color, hue averaging $52 \mathrm{H}^{\circ}$, USDA stage 6 ). On day $0, \approx 50$ fruit from each class of maturity were placed into $10-\mathrm{L}$ desiccators and subsequently exposed to $1-\mathrm{MCP}\left(250 \mathrm{~nL} \cdot \mathrm{L}^{-1}\right)$ as described below and held for $16 \mathrm{~h}$ at $22^{\circ} \mathrm{C}$. After treatment, fruit were held at $22{ }^{\circ} \mathrm{C}$ in air and held in the laboratory in covered cardboard trays. Although not controlled, relative humidity was $\approx 60 \%$ in the laboratory throughout. On day 10 , half of the $1-\mathrm{MCP}$ treated fruit were given a second exposure of 1-MCP for $16 \mathrm{~h}$. The once- and twice-exposed fruit were held for additional $11 \mathrm{~d}$ at $22{ }^{\circ} \mathrm{C}$. Ten fruit from each treatment were used for measurement of color changes and fruit firmness. Two color measurements were made per fruit on opposite sides along the fruit's equator, with one measurement being made from the most highly colored portion. Firmness measurements were made in an area adjacent to previous firmness measurements using a durometer (see below), which left a slight depression in the fruit surface; two measurements were made on each fruit on each sampling date. Color measurements were made at one-day intervals during the rapid ripening phase of the control fruit and less frequently thereafter. Firmness measurements were made on days 0,11 , and 22. Firmness data for days 11 and 22 were compared using Student's $t$ test. Only data significant at the $p \leq 0.05$ level are discussed.

To generate a concentration of $250 \mathrm{~nL} \cdot \mathrm{L}^{-1} 1-\mathrm{MCP}, 5 \mathrm{mg}$ EthylBloc powder was placed into a microcentrifuge tube and the 1 -MCP released from the cyclodextrin matrix using $100 \mu \mathrm{L}$ of 1 ${ }_{\mathrm{N}} \mathrm{KOH}$ to the well of the tube cap, the tubes were sealed, and the $\mathrm{KOH}$ solution mixed with the EthylBloc by shaking for 2 to $3 \mathrm{~s}$. The 1-MCP was administered by opening the microcentrifuge tube in the desiccator and immediately closing the container lid. Two to three hours were required to achieve a static concentration in the treatment chambers. The 1-MCP release was verified by GC analysis.

Fruit firmness was measured manually using a durometer (Shore Durometer Hardness Type 0-2, Shore Instrument and Mfg. Co., Jamaica, N.Y.) fitted with an 2.4-mm-diameter hemispherical probe. The durometer probe was pressed against the fruit tissue in a single smooth motion over 1 to $2 \mathrm{~s}$ and the maximum reading recorded. Data were recorded as hardness values and converted to SI units. To do this, the force (N) imparted by the durometer at various hardness values was measured using a top-loading balance. The amount of deformation of the durometer probe for any given force was measured using a micrometer so that units could be expressed as force per unit of deformation $(\mathrm{N} / \mathrm{mm})$.

EFFECT OF HARVEST STAGE AND 1-MCP ON VARIATION IN FRUIT COLOR. Tomatoes of the Roma-type 'Plum Dandy' cultivar were harvested without calyxes on 4 Sept. 1999 at the HTRC at MSU and immediately transported to the laboratory. Fruit were sorted into 3 ripeness classes, mature green (USDA stage 1), breaker (USDA stage 2) and pink (USDA stage 4). There were 100 fruit in each class. Fruit from each class were divided into two lots of 50 fruit each and stored in 10-L desiccators. One lot each from breaker and pink class were exposed to 1-MCP $\left(250 \mathrm{~nL} \cdot \mathrm{L}^{-1}\right)$ for $16 \mathrm{~h}$. At the end of this time, $\mathrm{O}_{2}$ levels were estimated to have declined to $\approx 10$ to $15 \mathrm{kPa}$ with $\mathrm{CO}_{2}$ increasing to 5 to $10 \mathrm{kPa}$, based on published respiratory rates for tomato (Hardenburg et 
al., 1986). Desiccators were subsequently ventilated and the lids replaced with the $4.5-\mathrm{cm}$-diameter stopper in the lids removed to enable free gas exchange with the laboratory air. Skin color of each fruit was measured on two locations per fruit as noted; data for hue angle are reported. The coefficient of variance for skin color was calculated for each assay date.

EFFECT OF 1-MCP ON LOCULAR GEL COLOR CHANGE RELATIVE TO SKIN COLOR. Tomatoes of the slicing-type cultivar 'Neptune' were harvested without calyxes at the apparent mature green stage of development from Southwest Florida Research and Education Center, University of Florida, Immokalee, Fla., on 22 May 2000. The fruit were shipped overnight on the day of harvest to East Lansing, Mich. The fruit were allowed to ripen the turning stage of ripeness at $22{ }^{\circ} \mathrm{C}$ without an exogenous ethylene treatment. It may be noted that all the harvested fruit were not at same initial stage of development and so did not reach the turning stage at the same time. Usually on any single day from day 3 postharvest and onward, 8 to 10 fruit would reach the turning stage of development. Each day, fruit reaching the turning stage were divided into two equal lots. Lot 1 were treated with $1-\mathrm{MCP}\left(250 \mathrm{~nL} \cdot \mathrm{L}^{-1}\right)$ for a period of $16 \mathrm{~h}$ and stored for $18 \mathrm{~d}$ at $22{ }^{\circ} \mathrm{C}$. Lot $2 \mathrm{did}$ not receive a 1-MCP treatment and was held for only $7 \mathrm{~d}$ at $22{ }^{\circ} \mathrm{C}$. Fruit were randomly assigned dates for analysis that ranged from 0 to $18 \mathrm{~d}$ posttreatment such that 3 fruit would be measured on each analysis date. Following storage, fruit were cut transversely into 7-mm-thick slices with a commercial slicing machine (FS 280 House and Home Electrical Food Slicer, Wholesale Merchandisers, Inc., Grand Rapids, Mich.). From each fruit, the three largest slices were used for slice quality assessment. Before slicing, fruit skin color was determined at two locations on each fruit as noted previously and the color of the locular gel determined after slicing at two locations on each slice. The regression of skin color and gel color was subjected to ANOVA and the slopes of the regressions tested for similarity using an F test.

EFFECT OF 1-MCP ON FRUIT VOLATILES, SUGARS, AND ACIDS. Fruit from two breeding lines, 308 and 311, were harvested without calyxes at mature green and turning stages of development from University of Florida Gulf Coast Research Center, Bradenton, Fla. The mature green (USDA stage 1) and turning fruit (USDA stage 3) were marked for identification. Twenty-four fruit of each cultivar at each stage of development were harvested for a total of 96 fruit. Each lot of 24 fruit representing a cultivar and developmental stage combination was divided into six sublots containing four fruit each. For each cultivar, three sublots of each developmental stage were combined and placed into each of two 5.6-L desiccators. Fruit in one desiccator were subsequently treated with 1-MCP and those in the other desiccator were left untreated. For 1-MCP treatment, a vial containing $10 \mathrm{mg}$ EthylBloc was placed in the desiccators for each variety and then all four desiccators were sealed. Release of 1-MCP gas from EthylBloc was activated by $300 \mu \mathrm{L}$ of $50: 50 \mathrm{KOH}-\mathrm{NaCl}$ buffer to yield $\approx 2$ $\mu \mathrm{L} \cdot \mathrm{L}^{-1} 1$-MCP. Following $15 \mathrm{~h}$ of 1 -MCP exposure, the $1-\mathrm{MCP}-$ treated and control fruit were removed from the desiccators and allowed to ripen at $21{ }^{\circ} \mathrm{C}$ at ambient humidity ( $\approx 50 \%$ to $60 \%$ ). The fruit were determined to be ripe when chromameter 'a' values around the equator of the fruit reached $30 \pm 3$ and remained there for $2 \mathrm{~d}$. At this time, sampling was performed for volatile, sugar, and acid analysis.

Fruit were homogenized in a blender (Warring Products Corp., N.Y.) at high speed for $30 \mathrm{~s}$, yielding $\approx 100 \mathrm{~mL}$ of homogenate. Three minutes after homogenization, $25 \mathrm{~mL}$ of the homogenate was decanted and blended for $10 \mathrm{~s}$ with $10 \mathrm{~mL}$ saturated (room temperature) $\mathrm{CaCl}_{2}$ to stop enzymatic reactions that can cause further changes in volatile levels (Buttery, 1993). The resulting homogenate was immediately flash frozen in liquid $\mathrm{N}_{2}$ and held at $-60{ }^{\circ} \mathrm{C}$ until analysis. Composite samples for each replication consisted of one to two fruit per sample. Flavor volatile components were analyzed according to the methods of Baldwin et al. (1998) using a gas chromatograph (model 8500; Perkin Elmer, Norwalk, Conn.) equipped with an HS-6 head space sampler and FID and injected onto a $0.53 \mathrm{~mm}$ i.d. $\times 30 \mathrm{~m}$ long column of $1.0 \mu \mathrm{m}$ film thickness (Stabilwax, Resteck Corp., Bellefonte, Penn.). The different compounds were identified by comparison of retention times with those of standards and by enrichment of tomato homogenate with authentic samples. Concentrations were calculated by using regression equations, determined by injecting five different concentrations of each standard to obtain a peak height calibration curve.

Forty milliliters of the original homogenate was stored at $-20{ }^{\circ} \mathrm{C}$ until prepared for analysis of solids, $\mathrm{pH}$ and titratable acidity, as well as HPLC analysis of individual sugars (glucose and fructose) was done according to Baldwin et al. (1998). Individual sugars were analyzed from $40 \mathrm{~g}$ homogenate extracted in $800 \mathrm{~g} \cdot \mathrm{L}^{-1}$ ethanol on a Sugar Pak column (Waters, Millipore Corp., Milford, Mass.). Levels of percent fresh weight glucose and fructose were converted to sucrose equivalents (SE) (Koehler and Kays, 1991), a term of relative sweetness based on sucrose where percent values for glucose and fructose were multiplied by 0.74 and 1.73 , respectively, and combined. Titratable acidity was measured for each homogenate sample according to Baldwin et al. (1998).

The data were analyzed by the analysis of variance (ANOVA) procedure using a statistics software package (SAS Institute, Cary, N.C.). ANOVA was done on data at each sampling date as well as for all treatment groups. All comparisons were made at the $95 \%$ confidence level. Unless otherwise stated, only data at $p \leq$ 0.05 are discussed.

CONTINUOUS EXPOSURE OF TOMATOES AT BREAKER AND PINK DEVELOPMENTAL STAGES. Breaker and pink 'Plum Dandy' tomatoes were harvested without calyxes on 12 Sept. 2000 at the HTRC of MSU. Thirty fruit of both ripeness stages were brought to the laboratory and divided into three lots of 10 fruit. One lot of fruit of each ripeness stage was placed into a 10-L desiccator and held at $22^{\circ} \mathrm{C}$. The desiccators were sealed and an air sample containing a high concentration of 1-MCP stock gas was injected in two of the desiccators, yielding a headspace 1-MCP concentration of 1 $\mu \mathrm{L} \cdot \mathrm{L}^{-1}$. After $16 \mathrm{~h}$, the untreated desiccator and one 1-MCP-treated desiccator were opened, ventilated, resealed, then continuously flushed with air humidified by passing it through a 1-L sidearm flask containing $\approx 200 \mathrm{~mL}$ of water at a flow rate of $50 \mathrm{~mL} \cdot \mathrm{min}^{-1}$ for the remainder of the study. Humidity in the desiccator was not determined, but was likely well below saturation since no condensate was visible on the chamber interior. The second 1MCP-treated desiccator was flushed with humidified air containing $1 \mu \mathrm{L} \cdot \mathrm{L}^{-1} 1-\mathrm{MCP}$ at a flow rate of $50 \mathrm{~mL} \cdot \mathrm{min}^{-1}$ for a continuous exposure treatment. The duration of the continuous treatment was $34 \mathrm{~d}$. Fruit color and firmness were measured every 1 to 3 $\mathrm{d}$ as previously described. After each measurement, a $1 \mu \mathrm{L} \cdot \mathrm{L}^{-1}$ concentration of 1-MCP was re-established in the chamber by injecting a volume of concentrated stock mixture.

The relationships between fruit skin color and firmness were fitted empirically using line-fitting software (Table Curve, Jandel Scientific, Inc., Chicago, Ill.); nontreated control data were fitted with a linear regression [firmness $=\mathrm{X}+\left(\mathrm{Y} \times\right.$ hue $\left.\left._{\text {skin }}\right)\right]$ and $1-\mathrm{MCP}$ 


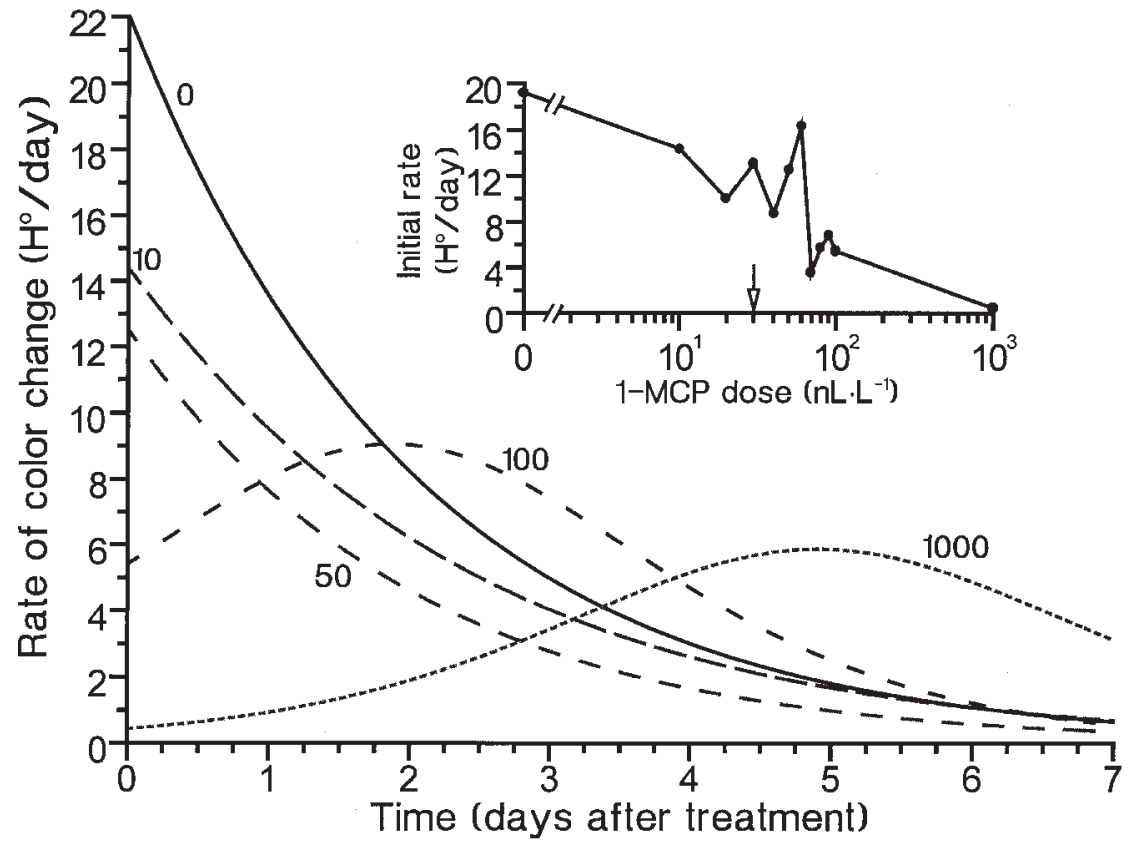

Results

CONCENTRATION DEPENDENCE OF COLOR DEVELOPMENT. The exponential curves fitting the data for time-dependent changes in hue had coefficients of determination $\left(r^{2}\right)$ varying between 0.936 and 0.999 , with an average of 0.983 and a $\mathrm{CV}$ of $1.6 \%$ (data not shown). From these curves, the first derivative estimate for the initial rate of color development for nontreated turning fruit was $\approx 22 \mathrm{H}^{\circ}$ day (Fig. 1). The initial rate following exposure to 1-MCP treatment declined as the concentration increased, falling to nearly zero at $1000 \mathrm{~nL} \cdot \mathrm{L}^{-1}$. The initial rate of skin color change was linearly dependent (negative slope) on the log of the 1-MCP concentration (Fig. 1, inset). The half-maximal response was obtained at $\approx 30 \mathrm{~nL} \cdot \mathrm{L}^{-1}$. The color change was at a maximal rate $5 \mathrm{~d}$ after application of $1000 \mathrm{~nL} \cdot \mathrm{L}^{-1}$ 1-MCP, $2 \mathrm{~d}$ after treatment with $100 \mathrm{~nL} \cdot \mathrm{L}^{-1}$, and 0 $\mathrm{d}$ after treatment with lower 1-MCP concentrations and nontreated controls.

COLOR AND FIRMNESS RESPONSES TO SINGLE

Fig. 1. Effect of 1-MCP concentration on the rate of color change of Roma-type 'Plum Dandy' tomatoes treated at the turning stage of development. Fruit were exposed to 1-MCP concentrations of $0,10,20,30,40,50,60,70,80,90,100$, and $1000 \mathrm{~nL} \cdot \mathrm{L}^{-1}$ for $16 \mathrm{~h}$ at $22^{\circ} \mathrm{C}$. Only data from $0,10,50,100$, and 1000 $\mathrm{nL} \cdot \mathrm{L}^{-1}$ are presented for clarity. $\mathrm{n}=2$ fruit, three measurements per fruit. Inset: Initial rate of color change; arrow indicates concentration for half-maximal response.

treatment data were fitted with a sigmoidal curve [firmness $=A+B$ $\times\left(\left(\right.\right.$ hue $\left.\left.\left._{\text {skin }}-\mathrm{C}\right) / \mathrm{D}\right) \times\left(\left(\left(\left(\text { hue }_{\text {skin }}-\mathrm{C}\right) / \mathrm{E}\right)^{2}\right)^{1 / 2}\right)^{(-\mathrm{F})}\right]$, where A, B $, \mathrm{C}, \mathrm{D}, \mathrm{E}$, $\mathrm{F}, \mathrm{X}$, and $\mathrm{Y}$ are variables that changed with initial ripeness stage.

The constant 1-MCP concentration for the continuous treatment was achieved using a programmable syringe pump (Genie, Kent Scientific Co., Litchfield, Conn.) and slowly emptying the contents of a $60-\mathrm{mL}$ syringe containing a high concentration of 1-MCP into the humidified air inlet stream of the desiccator. The pump was programmed to deliver $2 \mathrm{~mL}$ of concentrated 1-MCP gas per $\mathrm{h}$ to yield a $1-\mathrm{MCP}$ concentration of $\approx 1 \mu \mathrm{L} \cdot \mathrm{L}^{-1}$ within the treatment desiccator. The 1-MCP concentration in the exit line of the desiccator was measured once per day and did not drop below $0.8 \mu \mathrm{L} \cdot \mathrm{L}^{-1}$.

A concentrated stock mixture of 1-MCP gas was created and used to fill the syringes in the gas injection system. The stock mixture was made by placing $2.57 \mathrm{~g}$ of EthylBloc in a $0.5-\mathrm{L}$ jar. The jar was sealed with a lid that was fitted with two rubber serum stoppers. Fifty milliliters of $1 \mathrm{~N} \mathrm{KOH}$ buffer was added to the jar through one stopper and the 1-MCP release into the headspace was complete after $\approx 2 \mathrm{~h}$. Fifty milliliters of 1 -MCP gas was removed from the jar daily using a $60-\mathrm{mL}$ syringe. As each $50-\mathrm{mL}$ volume of gas was removed through one stopper, $50 \mathrm{~mL}$ of water was injected simultaneously through the other stopper, replacing the gas volume and preventing dilution of 1-MCP gas in the headspace of the stock mixture.

Fig. 2. Effect of a single (day 0) and two sequential exposures (days 0 and 10) to 1-MCP on skin color of Roma-type 'Plum Dandy' tomatoes during storage at $22{ }^{\circ} \mathrm{C}$. Initial maturity stages were mature green, breaker, pink, light red, and red. Open symbols represent untreated fruit, closed symbols represent fruit given a one (solid circles) or two (solid triangles) exposures to $250 \mathrm{~nL} \cdot \mathrm{L}^{-1}$ 1-MCP for $16 \mathrm{~h}$. Arrows represent a second 1-MCP application. $\mathrm{n}=10$ fruit, two measurements per fruit; bars are \pm SD.
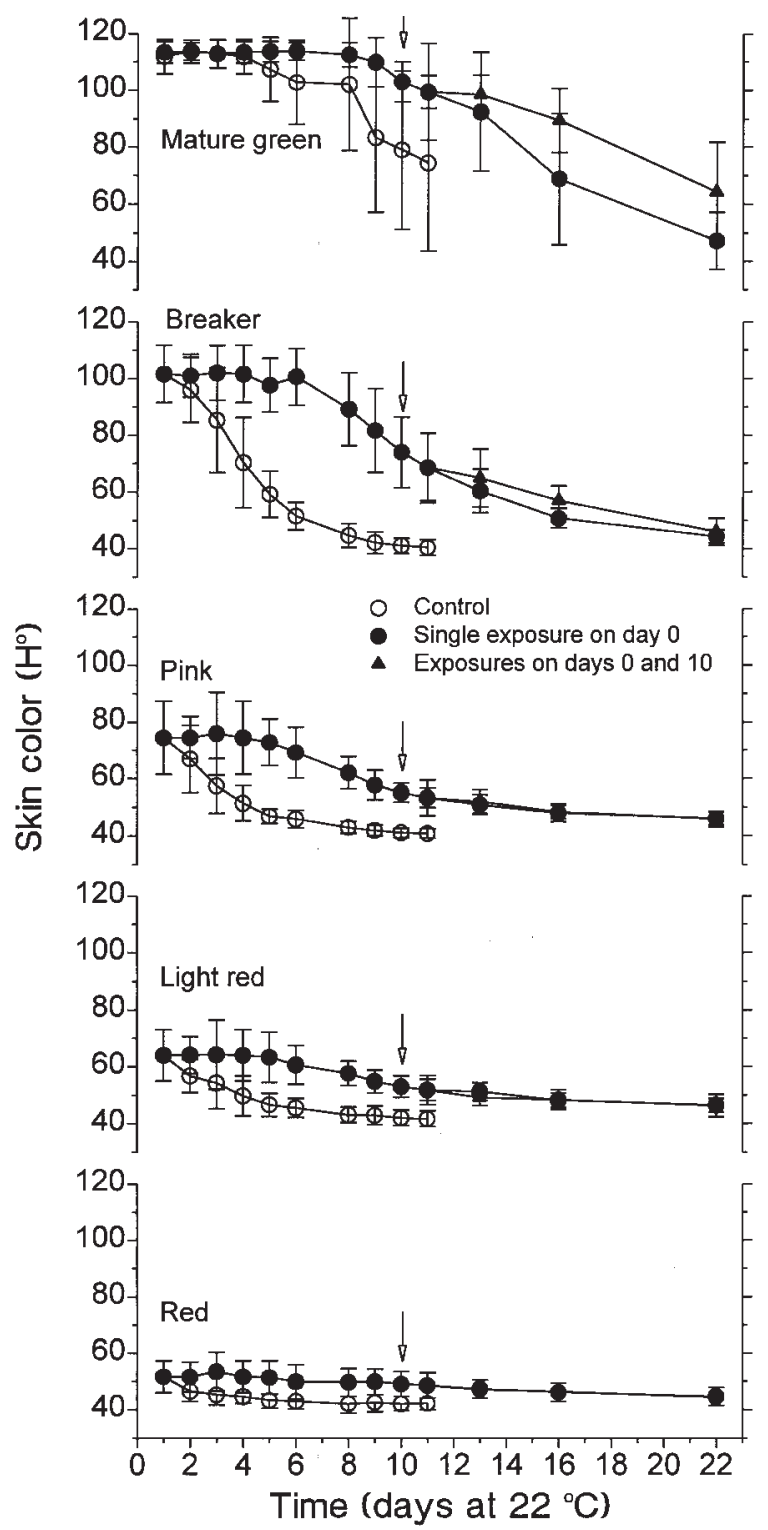


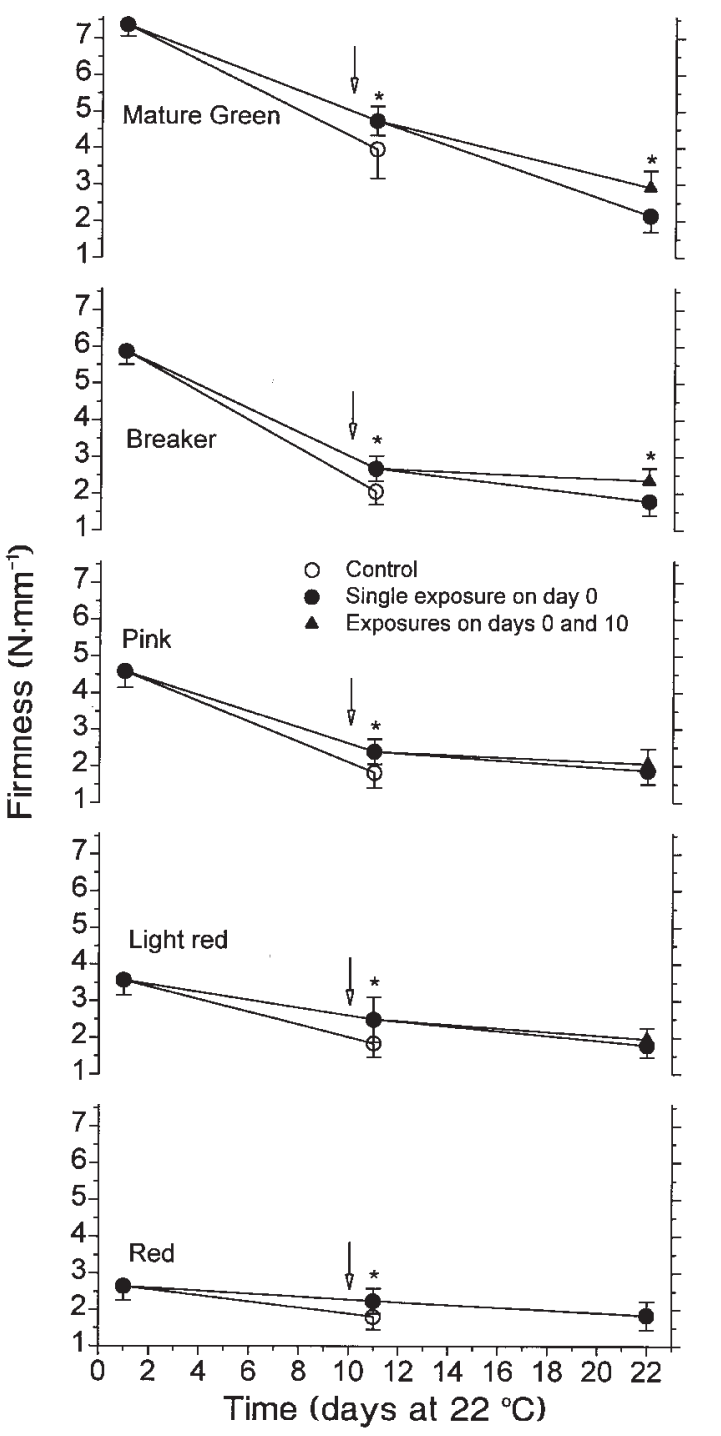

Fig. 3. Effect of a single (day 0 ) and two sequential exposures (days 0 and 10) to1$\mathrm{MCP}$ on the firmness of tomatoes during storage at $22^{\circ} \mathrm{C}$. Initial maturity stage were mature green, breaker; pink, light red, and red. Open symbols represent untreated fruit, closed symbols represent fruit given one (solid circles) or two (solid triangles) exposures to $250 \mathrm{~nL} \cdot \mathrm{L}^{-1} 1-\mathrm{MCP}$ for $16 \mathrm{~h}$. Arrows represent a second $1-\mathrm{MCP}$ application. $\mathrm{n}=10$ fruit; bars are $\pm \mathrm{SD}$. Asterisks indicate a significant effect of 1-MCP $(P<0.05)$.

AND SEQUENTIAL APPLICATIONS OF 1-MCP, AND INFLUENCE OF STAGE OF DEVELOPMENT. The application of $250 \mathrm{~nL} \cdot \mathrm{L}^{-1} 1-\mathrm{MCP}$ delayed the ripening-related color change for fruit at all stages of development (Fig. 2). The delay in color development relative to untreated controls appeared to be 5 to $6 \mathrm{~d}$ in each case. Fruit that were initially mature green and breaker responded to a second application of 1-MCP on day 10 with an additional decline in the rate of color change. Red color development of fruit harvested at later ripeness stages had advanced for all treatments by day 10 . The final color of 1-MCP-treated breaker, pink, light red, and red tended to be slightly less red than the final color of untreated fruit for each developmental stage. The treated and untreated mature green fruit did not ripen uniformly; some fruit remained green by the end of the study on day 22 , while others had developed full red coloration, resulting in high SD values.

Fruit firmness, expressed in units of force per unit of deformation, declined as the ripeness stage advanced (Fig. 3). Initial firmness values were 7.4, 5.9, 4.6, 3.5, and $2.7 \mathrm{~N} / \mathrm{mm}$ for mature green, breaker, pink, light red, and red, respectively. After $10 \mathrm{~d}$, 1-MCP-treated fruit were somewhat firmer than untreated fruit. Only mature green and breaker fruit responded to a second 1MCP application on day 10 by an improved retention in firmness relative to fruit receiving a single application.

EFFECT OF HARVEST STAGE AND 1-MCP ON FRUIT COLOR DEVELOPMENT. 1-MCP application delayed color development in breaker and pink 'Plum Dandy' tomatoes by $\approx 6$ to $8 \mathrm{~d}$ (data not shown). The large number of fruit in this study relative to other studies reported here helped to more accurately estimate fruit color variation. Initially, the coefficient of variation in fruit skin color was very low (3\% to $5 \%$ ) for mature green fruit, but increased 10 -fold to $\approx 45 \%$ as hue declined during ripening. The coefficient of variation in the skin color of nontreated controls and 1-MCP-treated fruit harvested at breaker and pink stages was $\approx 15 \%$ in the early stages of ripening. As fruit continued to ripen and hue declined, the CV of breaker- or pink-harvested fruit was between $5 \%$ and 15\%. 1-MCP had no effect on the variability of fruit color when fruit were treated at breaker or pink stages and it caused no discernable mottling.

EFFECT OF 1-MCP ON LOCULAR GEL COLOR RELATIVE TO SKIN COLOR. The skin color of nontreated, turning 'Neptune' tomatoes declined from $84 \mathrm{H}^{\circ}$ on day 1 to $40 \mathrm{H}^{\circ}$ on day 6 (Fig. 4). The

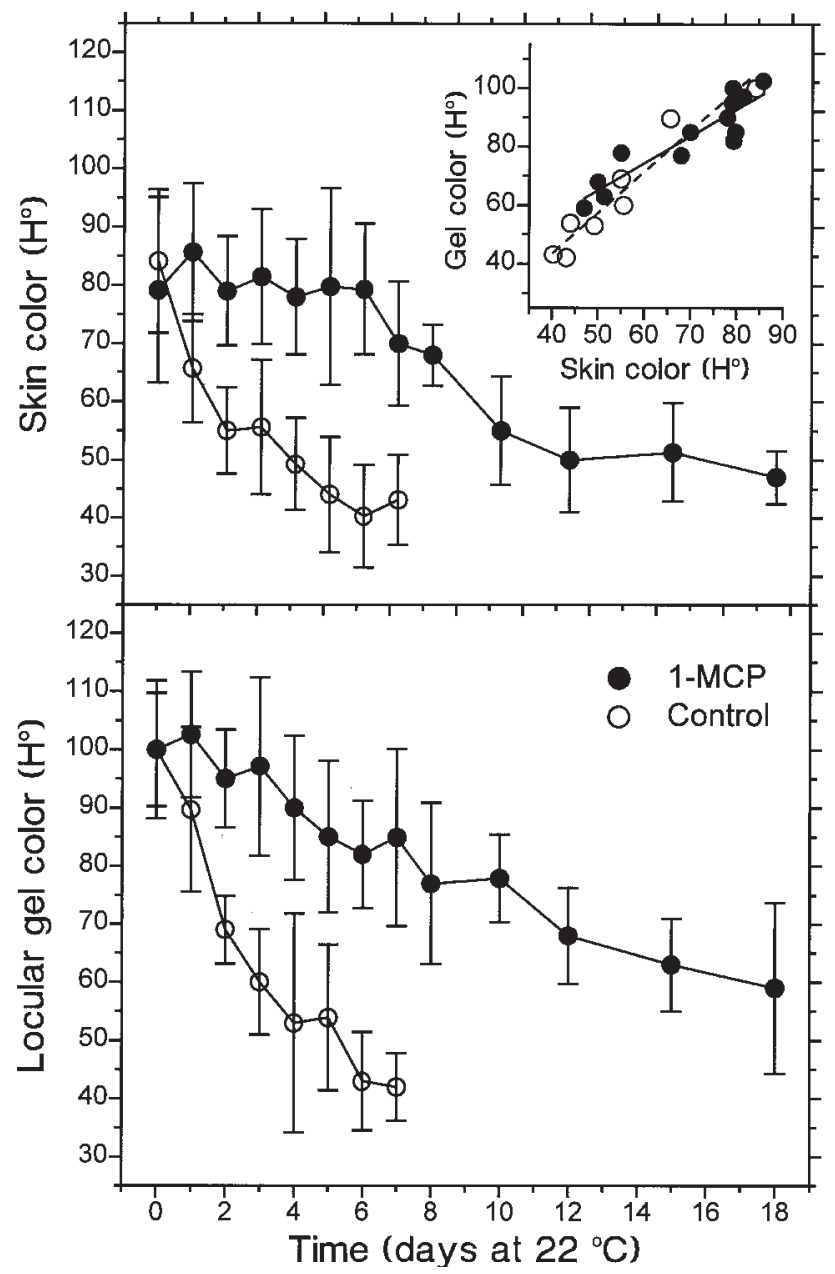

Fig. 4. Effect of 1-MCP on color (hue) of the skin (upper graph) and the locular gel (lower graph) of slicing-type 'Neptune' tomatoes during storage at $22{ }^{\circ} \mathrm{C}$. Fruit were treated with 1-MCP at the turning stage of ripening. Solid symbols represent fruit treated with $250 \mathrm{~nL} \cdot \mathrm{L}^{-1} 1-\mathrm{MCP}$ for $16 \mathrm{~h}$ on day $0 . \mathrm{n}=3$ fruit; bars are \pm SD. Inset: Linear regression of skin color against locular gel color for treated (solid symbols) and untreated (open symbols) fruit. 
Table 1. Effect of $1 \mu \mathrm{L} \cdot \mathrm{L}^{-1} 1-\mathrm{MCP}$ treatment (T) and stage of fruit development at harvest (S) for University of Florida slicing-type tomato breeding lines 308 and 311 (pooled data) on volatile compound concentration $\left(\mu \mathrm{L} \cdot \mathrm{L}^{-1}\right)$ in headspace over macerated tomato fruit after ripening to full color development at $22^{\circ} \mathrm{C}$. Volatiles are arranged by increasing retention time.

\begin{tabular}{|c|c|c|c|c|c|c|c|}
\hline \multirow[b]{2}{*}{ Compound } & \multicolumn{2}{|c|}{ Developmental stage } & \multicolumn{2}{|c|}{ Treatment } & \multicolumn{3}{|c|}{ Significance } \\
\hline & Mature green & Turning & Nontreated & 1-MCP & $\mathrm{S}$ & $\mathrm{T}$ & SxT \\
\hline Acetaldehyde & 7.54 & 20.8 & 11.6 & 16.8 & $* *$ & NS & NS \\
\hline Acetone & 0.269 & 0.337 & 0.308 & 0.299 & $* * *$ & NS & NS \\
\hline Ethanol & 12.9 & 23.3 & 13.1 & 23.0 & $*$ & $*$ & $*$ \\
\hline 1-Penten-3-one & 0.309 & 0.167 & 0.168 & 0.308 & $* * *$ & $* * *$ & NS \\
\hline 1-Hexanal & 3.76 & 10.7 & 10.1 & 4.28 & $* * *$ & $* * *$ & $* * *$ \\
\hline trans-2-Hexenal & 4.05 & 4.54 & 4.91 & 3.68 & NS & $* * *$ & NS \\
\hline trans-2-Heptenol & 0.026 & 0.038 & 0.028 & 0.037 & NS & NS & NS \\
\hline 6-Methyl-5-hepten-2-one & 0.289 & 0.337 & 0.372 & 0.254 & NS & $* * *$ & $* * *$ \\
\hline cis-3-Hexenol & 0.042 & 0.045 & 0.045 & 0.043 & NS & NS & NS \\
\hline 2-Isobutylthiazol & 0.021 & 0.033 & 0.030 & 0.024 & $*$ & NS & NS \\
\hline
\end{tabular}

locule color of these fruit underwent a similar rapid change, declining from $100 \mathrm{H}^{\circ}$ on day 1 to $45 \mathrm{H}^{\circ}$ on day 6 . The skin of fruit treated with $1 \mu \mathrm{L} \cdot \mathrm{L}^{-1} 1-\mathrm{MCP}$ did not change color during the first $6 \mathrm{~d}$, but declined thereafter to $\approx 50 \mathrm{H}^{\circ}$ by day 12 . $1-\mathrm{MCP}$ delayed red color development in the locule relative to untreated controls. The relationship between the skin and locular gel color of nontreated fruit was linear (hue $_{\text {gel }}=-12.7+1.40 \times$ hue $_{\text {skin }} ; r^{2}$ $=0.83$ ). The relationship between the skin and locular gel color of 1-MCP-treated fruit was also linear (hue $_{\text {gel }}=19.1+0.922 \times$ hue $\left._{\text {skin }} ; r^{2}=0.93\right)$. The rate of color change for the locular gel was lower $(p<0.05)$ than for nontreated fruit. The disparity in the coloration of the locule of the 1-MCP-treated fruit with that of the skin was greatest as the fruit skin attained its full coloration on day 12 , declining thereafter as the coloration of the locular material caught up with that of the skin.

EFFECT OF 1-MCP ON FRUIT AROMA, SUGARS, AND ACIDS. The effect of 1-MCP on volatile production after ripening was similar in both 308 and 311 breeding lines, hence only pooled data are shown (Table 1) and discussed. Turning-harvested fruit exhibited higher levels of six volatiles (acetaldehyde, acetone, ethanol, 1hexanal, 2 -isobutylthiazole, and $\beta$-damascenone+geranylacetone) than green-harvested fruit following ripening. 1-Penten-3-one and cis-3-hexenal, in contrast, were lower in turning-harvested than in green-harvested fruit. 1-MCP reduced the production of methanol, 1-hexenal,trans-2-hexenal, 6-methyl-5-hepten-2-one, and $\beta$-damascenone+geranylacetone, but enhanced ethanol, 1penten-3-one and cis-3-hexenal (Table 1). For ethanol, 1-hexenal, 6-methyl-5-hepten-2-one, and $\beta$-damascenone+geranylacetone, there was a significant developmental stage $\times 1$-MCP treatment interaction (Table 1). 1-MCP treatment and more advanced harvest promoted ethanol formation, but the $\mathrm{S} \times$ Tinteractions for the other three compounds differed in that $1-\mathrm{MCP}$ had an effect similar to a less mature harvest, causing reductions in each case.

When ripe (full red color development) nontreated fruit were compared to ripe 1-MCP-treated fruit, no effect of 1-MCP was found for $\mathrm{pH}$, soluble solids, fructose, glucose, or titratable acidity for fruit harvested mature green or turning (data not shown). After ripening, the average fructose and glucose contents for all fruit were $\approx 1.5 \%$ on a fresh weight basis, soluble solids averaged $5.2 \%, \mathrm{pH}$ averaged $\approx 4.5$, and titratable acidity was $\approx 0.45 \%$. For fruit harvested at the turning stage, 1-MCP-treated control fruit

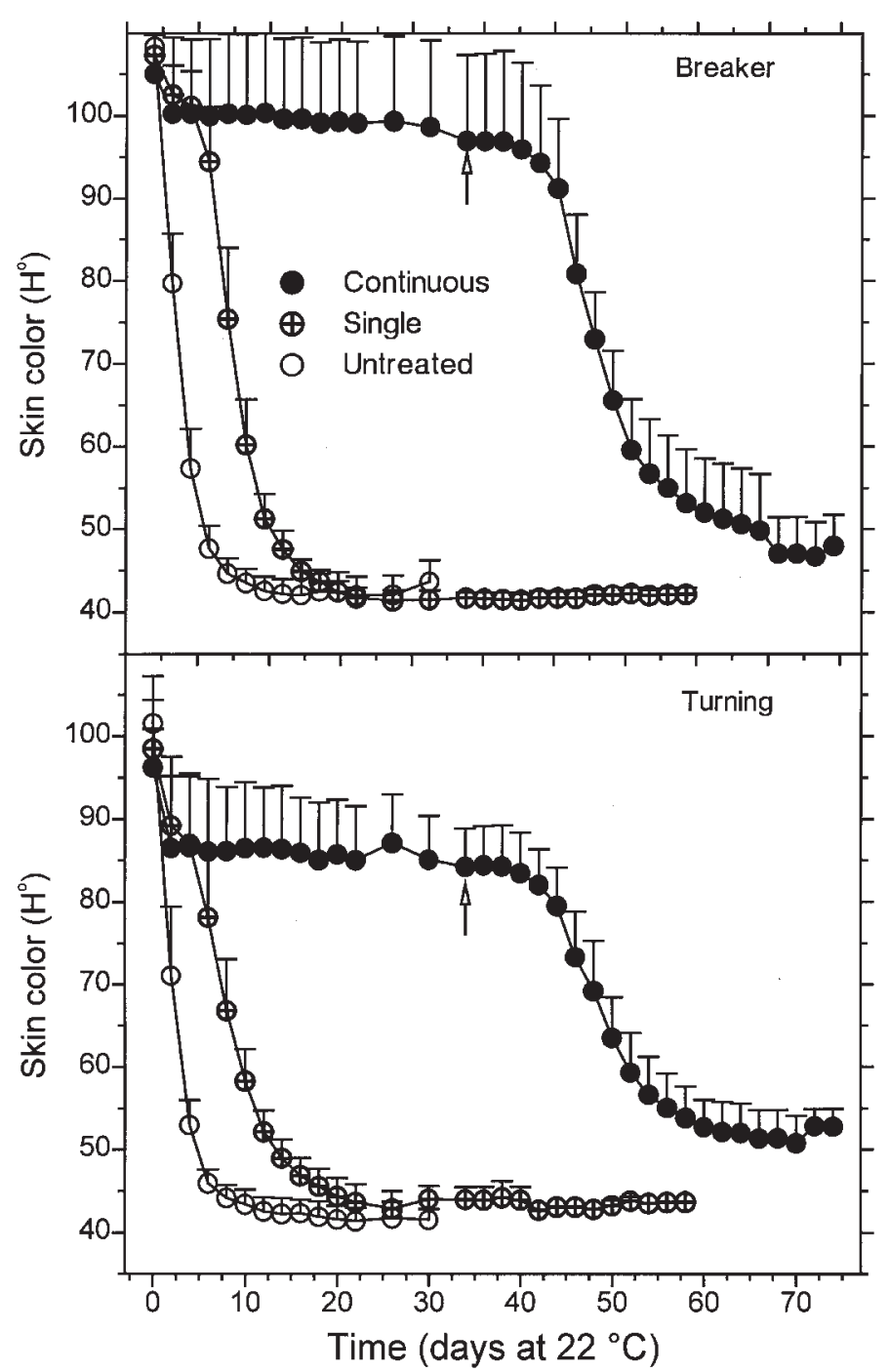

Fig. 5. Effect of a single and continuous exposure to 1-MCP on color (hue) of breaker and pink Roma-type 'Plum Dandy' tomatoes as a function of holding duration at $22{ }^{\circ} \mathrm{C}$. Open circles represent untreated fruit, open circles with crosses represent fruit treated once with $1 \mu \mathrm{L} \cdot \mathrm{L}^{-1}$ 1-MCP, and solid circles represent fruit treated continuously with $1 \mu \mathrm{L} \cdot \mathrm{L}^{-1} 1-\mathrm{MCP}$ for $34 \mathrm{~d}$. n $=5$ fruit, two measurements per fruit; bars are \pm SD. 


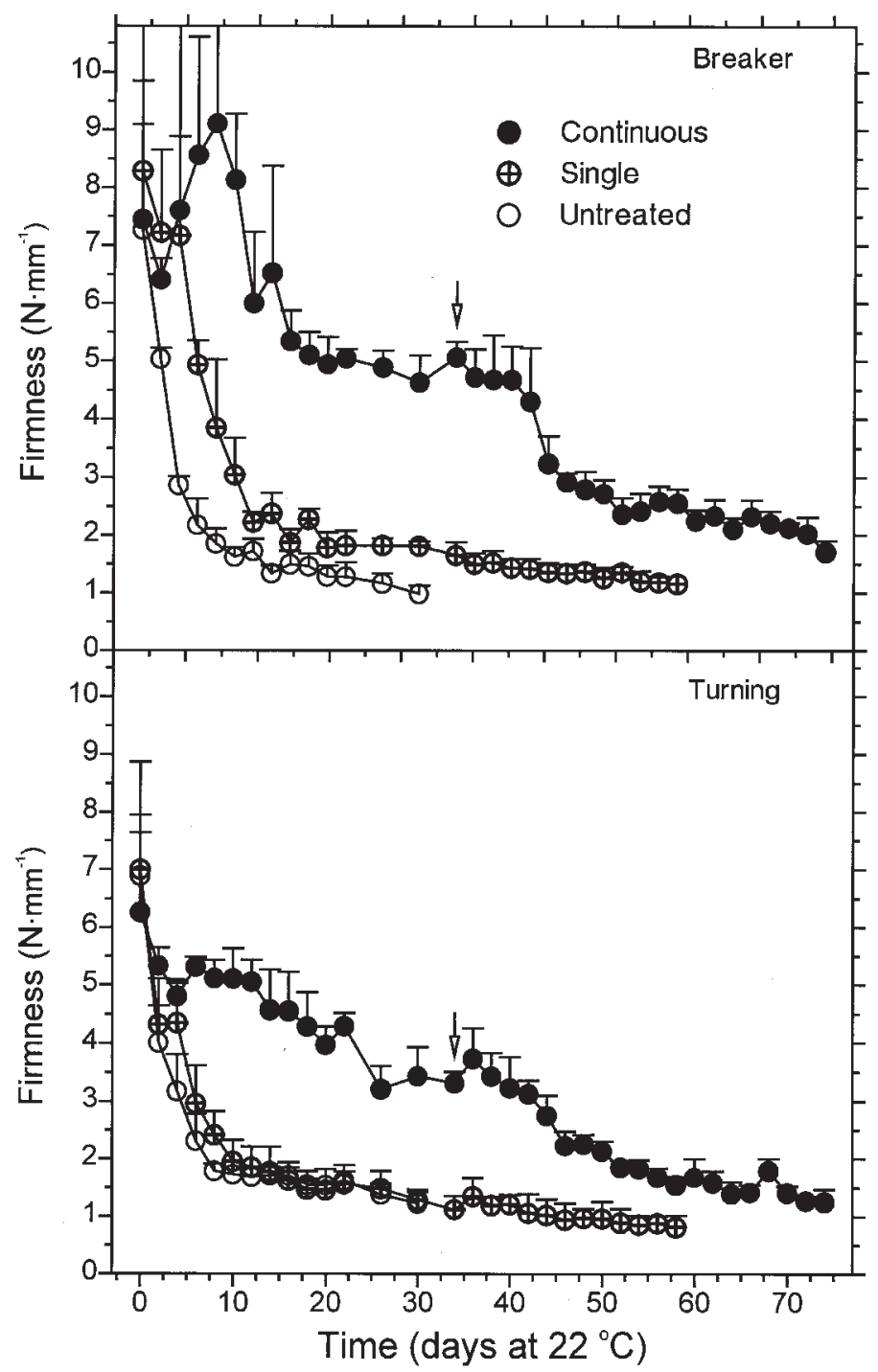

Fig. 6. Effect of a single and continuous exposure to 1-MCP on firmness of breaker and pink Roma-type 'Plum Dandy' tomatoes as a function of holding duration at $22{ }^{\circ} \mathrm{C}$. Open circles represent untreated fruit, open circles with crosses represent fruit treated once with $1 \mu \mathrm{L} \cdot \mathrm{L}^{-1} 1-\mathrm{MCP}$, and solid circles represent fruit treated continuously with $1 \mu \mathrm{L} \cdot \mathrm{L}^{-1} 1-\mathrm{MCP}$ for $34 \mathrm{~d} . \mathrm{n}=5$ fruit, two measurements per fruit; bars are \pm SD.

tended to have lower soluble solids, fructose, glucose, and total sugars and higher titratable acidity than fruit receiving 1-MCP treatment. As a result, the soluble solids/titratable acidity ratio was lower (9.5 vs. 13 , respectively) and sucrose equivalents were reduced ( 2.5 vs. 3.5 , respectively) for 1-MCP-treated fruit compared to nontreated fruit when harvested at the turning stage.

EFFECT OF CONTINUOUS EXPOSURE OF 1-MCPON SKIN COLOR AND FIRMNESS. Untreated breaker and pink fruit underwent rapid changes in hue as they ripened (Fig. 5). The maximum slope of the change in hue with time was $\approx 15 \mathrm{H}^{\circ} /$ day for

Fig. 7. Relationship between firmness and skin color (hue) of breaker and pink Roma-type 'Plum Dandy' tomatoes treated with $1 \mu \mathrm{L} \cdot \mathrm{L}^{-1} 1-\mathrm{MCP}$ (open symbols) or left untreated (closed symbols) for $34 \mathrm{~d}$. Data points are those depicted in Figs. 6 and 7. Data for a single 1-MCP treatment are not shown, but were similar to controls. Lines were fitted empirically using linear regression for nontreated control fruit [firmness $=X+\left(\times\right.$ hue $\left._{\text {skin }}\right)$ ] and using a sigmoidal curve for 1-MCP-treated fruit [firmness $=\mathrm{A}+\mathrm{B}$ $\times\left(\left(\right.\right.$ hue $\left.\left.\left._{\text {skin }}-\mathrm{C}\right) / \mathrm{D}\right) \times\left(\left(\left(\left(\text { hue }_{\text {skin }}-\mathrm{C}\right) / \mathrm{E}\right)^{2}\right)^{1 / 2}\right)^{(-\mathrm{F})}\right]$ to help depict trends. fruit at both stages of development. A single application of 1 $\mu \mathrm{L} \cdot \mathrm{L}^{-1} 1-\mathrm{MCP}$ for $16 \mathrm{~h}$ delayed color change for both breaker and pink fruit by $\approx 4$ to $6 \mathrm{~d}$. Upon recovery of color development in these fruit, the maximum rate of color change was $11 \mathrm{H}^{\circ}$ /day for breaker fruit and $6 \mathrm{H}^{\circ} /$ day for the more developmentally advanced pink fruit. Continuous application of 1-MCP essentially arrested color development for the $34 \mathrm{~d}$ of exposure and for an additional $6 \mathrm{~d}$ after exposure to 1-MCP was terminated. As continuouslyexposed fruit began to ripen, the maximum rate of color change was reduced relative to control or single treatment fruit, being 5 $\mathrm{H}^{\circ}$ /day for breaker fruit and $3 \mathrm{H}^{\circ}$ /day for pink fruit. The final hue for the continuously-treated fruit tended to be higher (less red) than untreated fruit or those fruit treated once with 1-MCP.

The average fruit firmness of breaker fruit at harvest was $\approx 7$ $\mathrm{N} / \mathrm{mm}$ and that of pink fruit was $\approx 5.5 \mathrm{~N} / \mathrm{mm}$ (Fig. 6). Firmness values higher than $7 \mathrm{~N} / \mathrm{mm}$ are considered suspect because they are near the limits of detection for the durometer. The fruit firmness of control fruit in both maturity classes declined rapidly, reaching minimum levels of $\approx 1.8 \mathrm{~N} / \mathrm{mm}$ within the first week of holding at $22{ }^{\circ} \mathrm{C}$. A single application of 1-MCP delayed the decline in firmness of breaker fruit by $\approx 6 \mathrm{~d}$; the delay in firmness decline of pink fruit was only $\approx 3 \mathrm{~d}$. Continuous application of 1 -MCP reduced the rate of softening in fruit of both classes of maturity.

The average firmness and corresponding average hue were regressed against one-another for breaker and pink fruit with and without continuous 1-MCP treatment (Fig. 7). The decline in firmness of untreated fruit of both ripeness stages was linearly related with a decline in hue (data for once-treated fruit are not shown). However, the relationship between fruit color and firmness for fruit continuously treated with 1-MCP was not linear and appeared to be sigmoidal in nature. Fruit underwent some softening without accompanying color change while under the influence of 1-MCP. After cessation of the continuous 1-MCP treatment, pink fruit with hues in the range of 60 to $80 \mathrm{H}^{\circ}$ and breaker fruit attaining hues from 60 to $90 \mathrm{H}^{\circ}$ were softer than untreated fruit with similar skin color. Final fruit firmness was similar for all treatments.

\section{Discussion}

The 4- to 8-d delay in the ripening of mature green tomatoes brought about by a single exposure to $1 \mu \mathrm{L} \cdot \mathrm{L}^{-1} 1-\mathrm{MCP}$ in the experiments reported here were similar to responses previously

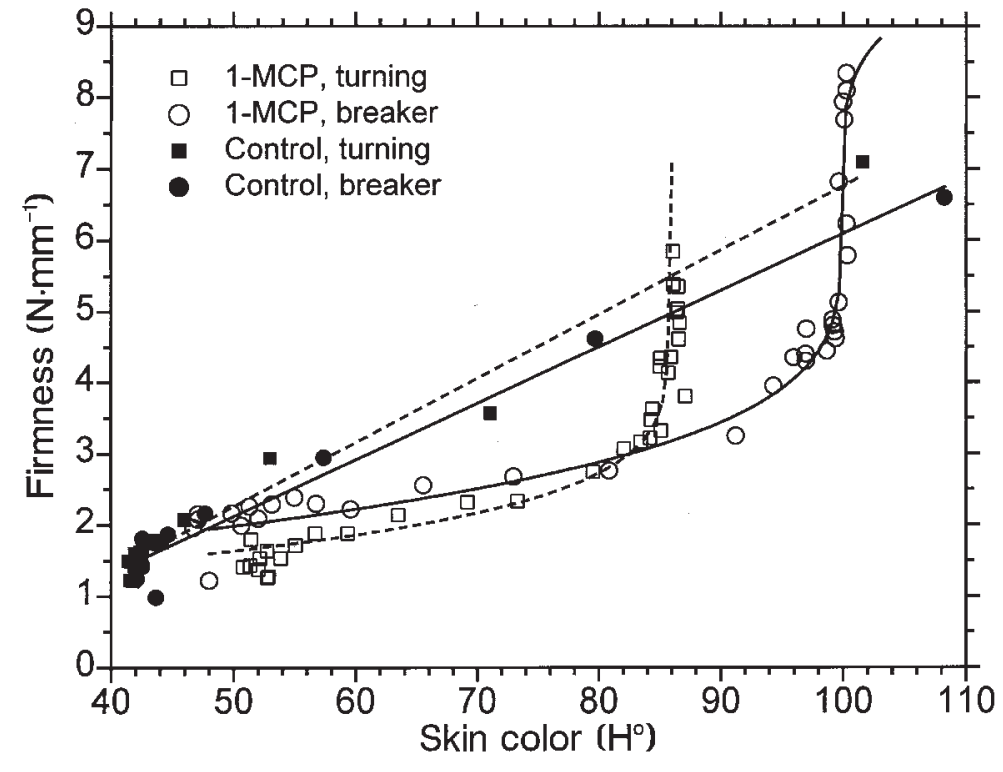


reported for tomatoes (Serek et al., 1995a; Sisler and Blankenship, 1996) and is consistent with the known mode of action of 1-MCP (Nakatsuka, 1998; Porat et al., 1995; Serek et al., 1995a; Sisler et al., 1996). These data on color development further support previous findings using silver ions (Hobson et al., 1984; Tucker and Brady, 1987) and ethylene perception mutants (Lanahan et al., 1994), demonstrating that normal color development and other ripening parameters in tomato are dependent on continuous ethylene action throughout ripening. The response to 1-MCP appears to be near saturation in the range of 250 to $1000 \mathrm{~nL} \cdot \mathrm{L}^{-1}$.

Our finding that a single 1-MCP treatment at $1 \mu \mathrm{L} \cdot \mathrm{L}^{-1}$ for 16 $\mathrm{h}$ helped to maintain firmness indicated that aspects of ripening, in addition to color change, are also suppressed by inhibiting ethylene action in tomato. The finding that multiple and continuous applications extended this benefit is similar to the finding by Mir et al. (2001) for apple fruit stored and treated multiple times at temperatures above $0{ }^{\circ} \mathrm{C}$. The data for the $34 \mathrm{~d}$ continuous exposure to $1 \mu \mathrm{L} \cdot \mathrm{L}^{-1} 1$-MCP suggest however, that some firmness loss can take place even if color development is halted. The work by Tucker and Brady (1987) shows that polygalacturonase activity, while prevented from increasing by silver treatment, does not decline, but is sustained for several days after treatment in all stages of ripeness tested and can account for the loss in firmness observed. This suggests that enzymes associated with textural changes, perhaps transcribed or translated before 1-MCP application, may still exert their influence, even though other aspects of ripening, such as color change, are arrested. It is also possible that some components of softening are ethylene-independent. The nature of the textural change described in this study is not clear due to the relatively crude instrumentation used. The degree of softening detected by the durometer may or may not translate into changes in firmness or texture perceptible by the consumer. Furthermore, the relationship between the firmness changes described here and susceptibility to handling and transportation damage needs to be clarified.

The volatiles cis-3-hexenal, cis-3-hexenol, cis-3-hexenol, hexanal, 1-penten-3-one, 3-methylbutanal, trans-2-hexenal, 6methyl-5-hepten-2-one, methyl salicylate, 2-isobutylthiazole, and ß-ionone influence tomato aroma (Baldwin, 2000; Buttery, 1993; Tandon et al., 2000). In general, volatile production is ripeningrelated and is thought to be dependent on ethylene production, although the exact relationship has yet to be established. The aroma volatile changes detected in ripe fruit, previously treated with1-MCP or nontreated, were rather minimal. In general, those volatiles that were altered did not increase by much more than 2 -fold, nor decrease by much more than $50 \%$. Nevertheless, those volatiles that were altered by 1-MCP treatment also tended to be altered in the same direction by harvesting fruit at an earlier stage of development. In this case, 1-penten-3-one and cis-3-hexenal were both enhanced and 1-hexenal, 6-methyl-5-hepten-2-one, and ß-damascenone were diminished by 1-MCP and by early harvest. The implication is that aspects of perceived flavor associated with an earlier harvest maturity, if any, may accompany 1-MCP treatment. All of these compounds are known to impact fruit aroma (Baldwin et al., 2000) and flavor quality is often a concern for fruit harvested at an early stage of maturity (Bisogni et al., 1976; Maul et al., 1998a, 1998b). Fruit ripened on the vine past breaker stage and then harvested have a better flavor than ethylene-ripened mature green fruit (Bisogni et al., 1976; Kader et al., 1977). Green fruit that are less physiologically mature produce lower levels of 1-penten-2-one, cis-3-hexenal, 6-methyl-5-hepten-2-one, 2isobutylthiazole, and geranylacetone than the ripe fruit (Maul et al., 1998a). The fact that some of these volatiles are unaffected, some are enhanced, and some are diminished by 1-MCP prevents precise prediction of the nature of the impact of 1-MCP on aroma. However, the relatively small magnitude of changes in volatile concentrations suggests that the perception of aroma by consumers may be minimally impacted, if at all. Nevertheless, resolution of the question of a negative or positive flavor impact by 1-MCP will require the use of sensory panels.

The lack of a marked effect of $1 \mu \mathrm{L} \cdot \mathrm{L}^{-1} 1-\mathrm{MCP}$ on sugar and acid concentrations following ripening of treated fruit to the same degree as nontreated controls suggests that taste, like aroma, may be similar for treated fruit and nontreated fruit (Baldwin et al., 2000). The data indicate that processes affecting sugar and acid changes during ripening are similar for nontreated and 1MCP-treated fruit despite the fact that the processes are delayed by 1 -MCP.

Tomato ripening starts in the fruit interior with gel formation in the locule (Atta-Aly et al., 2000; Brecht, 1987). Ripening, as measured by change in color, then occurs in the placenta tissue, columella, radical pericarp, and eventually the outer pericarp (Brecht, 1987). The differential response of locule gel and skin color development to a single dose of $1 \mu \mathrm{L} \cdot \mathrm{L}^{-1} 1-\mathrm{MCP}$, may compromise the use of 1-MCP for tomato destined to be used for slices. To the eye, the locular gel of 1-MCP-treated fruit was noticeably greener than that of nontreated fruit ripened to the same external color in the variety used in this study. The delay in locular gel coloration may be due to restricted diffusion of $1-\mathrm{MCP}$ out of the gel tissue following treatment. The fact that diffusion of gasses in air is roughly 10,000 times greater than in liquid (Burton, 1974) supports this possibility.

The growth regulator 1-MCP has significant potential for its integration into cultural practices associated with the storage tomato. Arresting fruit ripening may be a commercially exploitable feature of 1-MCP action on tomato, particularly for fruit in the early stages of ripening. Advantages may include eliminating the need to gas fruit with ethylene to initiate ripening, elimination of the harvest of immature fruit, improved uniformity of red color formation and ripening, avoiding the need for repacking, and a reduction in the need for refrigeration which also is detrimental to flavor (Maul et al., 2000).

These advantages are contingent upon the 1-MCP treatment not having a deleterious effect on texture, flavor, appearance, and decay resistance. Potential negative attributes detected include volatile alteration, a mismatch in color development of the locular gel and the skin, reduced tissue firmness relative to that expected due to skin color, a slowed rate of ripening during recovery from treatment, especially following long treatment durations, and a reduction in final red color intensity. While fruit decay was not obviously enhanced by 1-MCP treatment, this possibility should be evaluated further, given the reduced pathogen resistence found for vegetative tissues of 1-MCP-treated and ethylene-insensitive plants (Díaz et al., 2002). Potential drawbacks may be too minor to appreciably impact quality at the consumer level, particularly for fruit harvested at pink or later stages of maturity when flavor and taste attributes are well-developed. Sensory tests will provide needed information regarding the fit of this new growth regulator into the cultural practices in tomato handling and storage.

\section{Literature Cited}

Atta-Aly, M.A., J.K. Brecht, and D.J. Huber. 2000. Ripening of tomato fruit locule gel tissue in response to ethylene. Postharvest Biol. Technol. 19:239-244. 
Baldwin, E.A., J.W. Scott, M.A. Einstein, T.M.M. Malundo, B.T. Carr, R.L. Shewfelt, and K.S. Tandon. 1998. Relationship between sensory and instrumental analysis for tomato flavor. J. Amer. Soc. Hort. Sci. 123:906-915.

Baldwin, E.A., J.W. Scott, C.K. Shewmaker, and W. Schuch. 2000. Flavor trivia and tomato aroma biochemistry and possible mechanisms for control of important aroma compounds. HortScience 35:1013-1022.

Bisogni, C.A., G. Armbruster, and P.E. Brecht. 1976. Quality comparisons of room ripened and field ripened tomato fruit. J. Food Sci. 41: 333-338.

Brecht, J.K. 1987. Locular gel formation in developing tomato fruit and the initiation of ethylene production. HortScience 22:476-479.

Burton, W.G. 1974. Some biophysical principles underlying the controlled atmosphere storage of plant material. Ann. Appl. Biol. 78:149-168.

Buttery, R.G. 1993. Quantitative and sensory aspects of flavor of tomato and other vegetables and fruit, p. 259-286. In: T.E. Acree and R. Teranishi (eds.). Flavor science: Sensible principles and techniques. Amer. Chem. Soc., Wash., D.C.

Díaz, J., A ten Have, and A.L. van Kan. 2002. The role of ethylene and wound signaling in resistance of tomato to Botrytis cinerea. Plant Physiol. 129:1341-1351.

Hardenburg, R.E., A.E. Watada, and C.Y. Wang. 1986. The commercial storage of fruit, vegetables, and florist and nursery stocks, USDA Hndbk. 66.

Hobson, G.E., R. Nichols, J.N. Davies, and P.T. Atkey. 1984. The inhibition of tomato fruit ripening by silver. J. Plant Physiol. 116:21-29.

Hoeberichts, F.A., L.H.W. van der Plas, and E.J. Woltering. 2002. Ethylene perception is required for the expression of tomato ripening-related genes and associated physiological changes even at advanced stages of ripening. Postharvest Biol. Technol. 26:125-133.

Kader,A.A. and L.L. Morris. 1976. Correlating subjective and objective measurements of maturation and ripeness of tomatoes. In: Proc $2^{\text {nd }}$ Tomato Quality Wkshp., Veg. Crops Ser. 178. Univ. Calif., Davis.

Kader, A.A., L.L. Morris, M.A. Stevens, and M. Albright-Holton. 1978. Composition and flavor quality of fresh market tomatoes as influenced by some postharvest handling procedures. J. Amer. Soc. Hort. Sci. 103:6-13.

Kader,A.A., M.A.Stevens, M.Albright-Holton,L.L. Morris, and M.Algazi. 1977. Effect of fruit ripeness when picked on flavor and composition in fresh market tomatoes. J. Amer. Soc. Hort. Sci. 102:724-731.

Koehler, P.E. and S.J. Kays. 1991. Sweet potato flavor: Quantitative and qualitative assessment of optimum sweetness. J. Food Qual. 14: 241-249.

Lanahan, M.B., H-C. Yen, J.J. Giovannoni, and H.J. Klee. 1994. The never-ripe mutation blocks ethylene perception in tomato. Plant Cell 6:521-530.

Maul, F., S.A. Sargent, C.A. Sims, E.A. Baldwin, M.O. Balaban, and D.J. Huber. 2000. Tomato flavor and aroma quality as affected by storage temperature. J. Food Sci. 65:1228-1236.

Maul F., S.A. Sargent, M.O. Balaban, E.A. Baldwin, D.J.Huber, and C.A. Sims. 1998a. Aroma volatile profiles from ripe tomatoes are influenced by physiological maturity at harvest: An application for electronic nose technology. J. Amer. Soc. Hort. Sci. 123:1094-1101.

Maul, F., S.A. Sargent, D.J. Huber, E.A. Baldwin, and C.A. Sims. 1998b. Predicting flavor potential for green-harvested tomato fruit. Proc. Fla. State Hort. Soc. 111:285-290.

Maul, F., S.A. Sargent, E.A. Baldwin, C.A. Sims, and D.J. Huber. 1997. Sensory evaluation correlates with flavor volatile profiles of ripe tomato fruits. HortScience 32:521.

Mir, N., E. Curell, N. Khan, M. Whitaker, and R.M. Beaudry. 2001. Harvest maturity, storage temperature, and 1-MCP application frequency alter firmness retention and chlorophyll fluorescence of 'Redchief Delicious' apple fruit. J. Amer. Soc. Hort. Sci. 126:618-624.

Mir, N., N. Khan, and R.M. Beaudry. 1999. 1-Methylcyclopropene extends shelf-life of tomato at all stages of maturity. HortScience 34: 538 (abstr.).

Nakatsuka A., S. Murachi, H. Okunishi, S. Shiomi, R. Nakano, Y. Kubo, and A. Inaba. 1998. Differential expression and internal feedback regulation of 1-aminocyclopropane-1-carboxylate synthase, 1-aminocyclopropane-1-carboxylate oxidase, and ethylene receptor genes in tomato fruit during development and ripening. Plant Physiol. 118:1295-1305.

Porat, R., E. Shlomo, M. Serek, E.C. Sisler, and A. Borochov. 1995. 1-Methylcyclopropene inhibits ethylene action in cut phlox flowers. Postharvest Biol. Technol. 6:313-319.

Rohwer, C.L., and R.J. Gladon. 2001. 1-Methylcyclopropene delays ripening of pink and light red tomatoes. HortScience 34:466 (abstr.).

Serek, M., E.C. Sisler, and M.S. Reid. 1995a. 1-Methylcyclopropene, a novel gaseous inhibitor of ethylene action, improves the life of fruits, cut flowers and potted plants. Acta Hort. 394:337-347.

Serek, M., E.C. Sisler, and M.S. Reid. 1995b. Effect of 1-MCP on the vase life and ethylene response of cut flowers. Plant Growth Regul. 16:93-97.

Serek, M., E.C. Sisler, T. Tirosh, and S. Mayak. 1995c. 1-Methylcyclopropene prevents bud, flower, and leaf abscission of Geraldton Waxflower. HortScience 30:1310.

Sisler, E. and S. Blankenship. 1996. Patent No. 5,518,988. Method of counteracting an ethylene response in plants. 21 May.

Sisler, E.C., M. Serek, and E. Dupille. 1996. Comparison of cyclopropene, 1-methylcyclopropene, and 3,3-dimethyl cyclopropene as ethylene antagonists in plants. Plant Growth Regulat. 18:169-174.

Tandon, K.S., E.A. Baldwin, and R.L. Shewfelt. 2000. Aroma perception of individual volatile compounds in fresh tomatoes (Lycopersicon esculentum Mill.) as affected by the medium of evaluation. Postharvest Biol. Technol. 20:261-268.

Tucker, G.A. and C.J. Brady. 1987. Silver ions interrupt tomato fruit ripening. J. Plant Physiol. 127:165-169.

USDA, U.S. Dept. of Agriculture. 1975. Visual aid TM-L-1. The John Henry Co., Lansing, Mich.

U.S. Dept. of Agriculture. 1976. United States standard grades of fresh market tomatoes. USDA, Wash., D.C.

Wills, R.B.H. and V.V.V. Ku. 2002. Use of 1-MCP to extend the time to ripen of green tomatoes and postharvest life of ripe tomatoes. Postharvest Biol. Technol. 26:85-90. 